\title{
Gender Portrayal In English Learning Materials: Teachers' Perspective
}

\author{
Siti Azisah \\ Universitas Islam Negeri Alauddin \\ Makassar, Indonesia \\ azisahsiti@gmail.com
}

\begin{abstract}
This paper aimed to present the teachers' perspective on gender portrayal in English learning material at an Islamic Schools in South Sulawesi. This research employs participatory action research. Where the teachers as the research participant actively participated in showing their own views about gender portrayal in English teaching materials that they used. The participant of this research were the teachers of English in every level of grades namely grade VII, grade VIII and grade IX. There were three teachers involved in total. Data collected by following a number of research procedures such as participatory mapping the problem, making conclusion and acting and observing. The research covered several category of gender portrayal in textbooks which were male and female visibility, balance/equal, balance but stereotyped, balance and non-stereotyped. The result showed the researcher revealed that the perspectives of the teachers were similar with those categories.
\end{abstract}

\section{Keywords—-gender; portrayal; learning materials}

\section{INTRODUCTION}

Gender is a social construction of what society expects from the fact of being a man or a woman concerning their roles and responsibilities, characteristics, aptitudes and behaviors [1].

Gender roles, traits, behaviors were inculcated to children in schools curriculum and teaching materials which played crucial roles for this matters.

Teaching material/textbooks portrayed males and females differently. The study of gender portrayal in curriculum and learning materials and/or textbooks had been documented by a number of researchers. Many researchers covered the school textbooks were male predominant and women tend to be invisible in representation [2]. Other researches revealed male predominant in school textbooks and curriculum material [3][5]. Further researches on textbooks uncovered stereotyped gender portrayal [6] Many efforts had been done to address those gender portrayals.

The government of Indonesia had commissioned women studies centers to work with publishers, writers and illustrators for the publication of gender fair textbooks in 2004. Furthermore, the UNESCO published a Methodological guide for Promoting gender equality through textbooks written by
[7]. It was hoped by the efforts to improve gender equality including the equal gender portrayal.

The turn of the Millennium and the following years made a difference. My research on school textbook indicated that the textbook published in and after 2004 were more progressive in gender representation: women were more visible and nonstereotyped depiction were present [8].

The study of teacher perspective on gender portrayal is very small. My previous research examined the perspective of the school community on gender roles in three Islamic primary schools as a part of a big study on gender mainstreaming in education. My research discovered that the school community including principal, teachers and school committee shared stereotyped gender ideology [9].

They believed men as the main income earners in the family while women responsible for domestic duties. Men could only do domestic duties if women were not available or unable to do the jobs because of sickness. If a man did domestic job, he was assumed to help a woman to do the job. In the vice-verse, if a woman work outside home to earn a living, she was only considered as the secondary earner and she still responsible for the home duties. I also uncovered that the school community believed that a man is a leader over women. A woman could be in a leader position if she had capability but a man was the priority for leader.

\section{Methodology}

This research employs participatory action research. Where the teachers as the research participant actively participated in showing their own views on gender portrayal in English teaching materials that they used. The research was conducted in a State Islamic Junior High School called MTsN Balang-Balang. The participant of this research were the teachers of English in each level of grades namely gradeVII, grade VIII and grade IX. Three teachers involved in total. Data collected by following a number of research procedures such as participatory mapping the problem, making conclusion and acting and observing.

\section{RESULT AND DISCUSSION}

The State Islamic Junior High School Balang-Balang used the 2013 Curriculum started from 2015/2016 academic year for grade VII. The other grades started to implement the 2013 
curriculum in 2016/2017 academic year. Furthermore, the 2013 curriculum is ready to implement since the supporting material for implementation are available including syllabus and textbooks both electronic books and hard copy book. Teachers was only looking the supplementary teaching resources.

However, Teachers in State Islamic Junior High School in Balang-Balang did not relied on textbooks provided by the Ministry of Education and Culture. Instead, as the curriculum practitioners, teachers tried to find out other teaching materials to serve the 2013 curriculum. Moreover, the three teachers in this school used varied textbooks. The teacher of grade VII use four textbooks. The textbooks were not all newly publication but also the old publication. The book used by the grade VII were: Passport to the World 2009, When English Rings the Bell 2013, BUPENA 2014, Bright 2014. The teacher of Grade VIII used only one main textbook Bright 2014. The teacher of grade IX also used one main textbooks called "Headline English" published 2016. The three teachers from three grade levels used various English textbooks based on the availability for teachers and students and the textbooks were suitable with the 2013 curriculum.

According to teachers' perspective on gender portrayals was found the following perspective of the teachers:

\section{A. Balancelequal gender portrayal}

The teacher of grade IX started to identify the cover

of the book who portray gender roles equally. She also identified the equity depiction of male and female students who wore Muslim dress. The book portray both of them walking together to school. The picture of male and female was equal. Both male and female were visible and nonstereotype.

The teacher of grade VIII also identified the equal gender representation starting from the cover of the textbook used. She appreciated that the number of male and female were balance. She also identified the gender roles in that picture as equal. She said that all people (males and females) in that picture hold books. All of them focused their attention in one object, and they were smile and hold each other's shoulder. This teacher perceived this picture as the most ideal of gender equality.

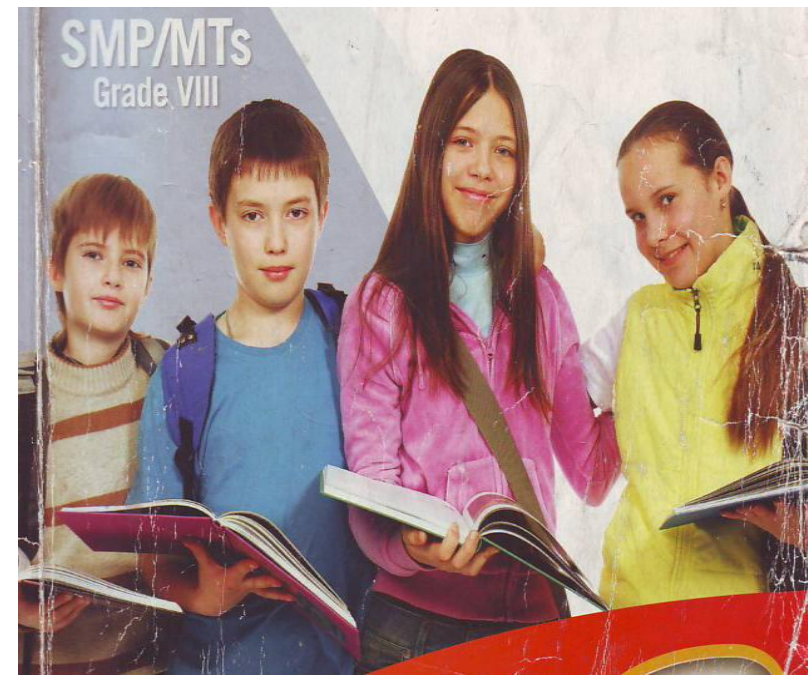

Fig. 1. Gender portrayal of the book cover

\section{B. Balance but stereotyped gender portrayal}

The teachers of State Islamic Junior High School identified Gender Stereotypes: gender stereotypes Gender stereotype was defined by Shaw (cited in Gooden and Gooden 2001:90) as 'assumptions made about characteristics of each gender, such as physical appearance, physical abilities, attitudes, interests, or occupation.

The teacher of grade VII had gender stereotyped views in three kinds of gender depiction: traits, leadership, and profession. The stereotyped views of this teacher can be seen as follows. First, the stereotyped views of gender traits such as the teacher assume that a woman had to had interesting and beautiful physical appearance and friendly attitude as she said in Bahasa "perempuan harus tampil menarik, cantik dan ramah (a woman have to have interesting and beautiful physical appearance and to interact in friendly attitude" when she saw a picture a woman standing. The other stereotyped view of the teacher was in leadership position. she said "lakilaki merupakan pemimpin bagi perempuan (a man is a leader over women" when she identified the portrayal of a man giving guidance to a woman. Therefore, the stereotyped gender role depiction in the teaching material is fine. Another gender stereotyped views of the teachers was in occupation. Women were suitable to have profession as teachers. The teacher's argument were related to the stereotyped attitude of women to be caring and tolerant. The teacher also perceived that women had compassionate and gentle in physical appearance. While men were tough, strong and secure.

The teacher of grade VIII identified balance in terms of number of male and female in the picture, yet the role they were portrayed was in stereotyped way. Male depicted as master chef, and female as assistance chef. 


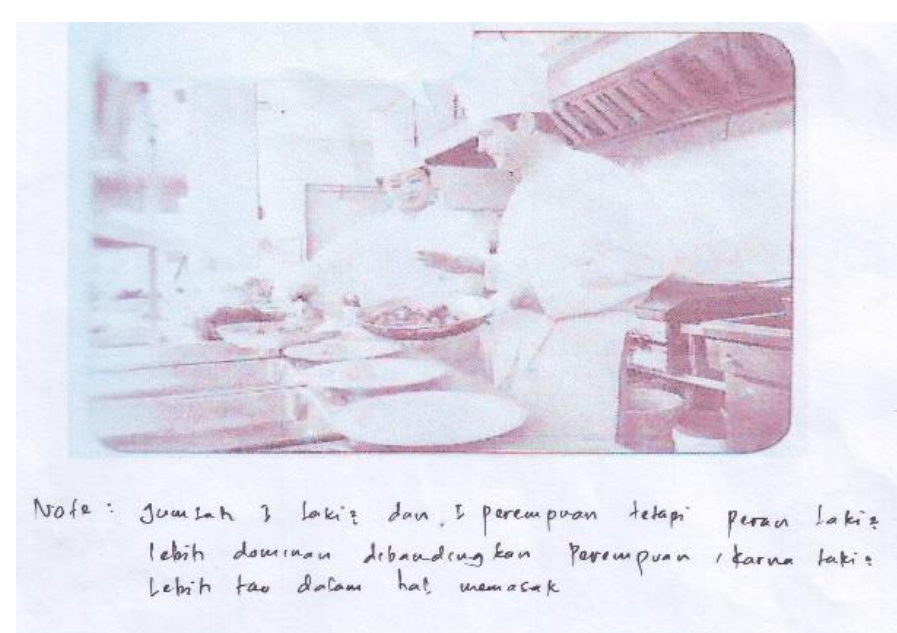

Fig. 2. A male and a female chef

Another picture identified as balance in quantity but stereotype in gender roles and trait. The stereotyped of this picture was actually not identified as a gender issues. The picture about a female librarian and a male assistance. The librarian was walking without burden and the male assistant was in heavy burden of bringing books. The heavy burden of male was fine since a man was stronger than a woman. Yet, this image was actually progressive in term of promoting women in powerful position as a librarian instead as assistance.

\section{CONCLUSION}

The English learning material portrayed gender in both equal and stereotyped way. There were more gender balance but stereotyped than equal gender representation. In choosing the learning materials, teachers did not considered gender portrayal in textbooks of English learning material. The teacher themselves perceived gender portrayal in learning material similar with the depiction in the books.

\section{References}

[1] K. Hughes, "'I've been pondering whether you can be a part-feminist': Young Australian Women's Studies students discuss gender," in Women's Studies International Forum, 2005, vol. 28, no. 1, pp. 37-49.

[2] D. SPENDER, "Invisible Women: the schooling scandal (London, Writers and Readers Publishing Co-operative)," Spend. Women Sch. Scandal., 1982.

[3] J. Abraham, "Teacher ideology and sex roles in curriculum texts," $B r . J$. Sociol. Educ., vol. 10, no. 1, pp. 33-51, 1989.

[4] M. Logsdon, "Gender roles in elementary school texts in Indonesia," Women Asia Pacific Towar. an East-West Dialogue, Ed. by M. Goodman, pp. 243-262, 1985.

[5] P. Mahony, "How Alice's chin really came to be pressed against her foot: Sexist processes of interaction in mixed-sex classrooms," in Women's Studies International Forum, 1983, vol. 6, no. 1, pp. 107-115.

[6] L. Parker, "Engendering school children in Bali," J. R. Anthropol. Inst., pp. 497-516, 1997.

[7] C. Brugelles and S. Cromer, "Promoting gender equality through textbooks," A Methodol. Guid. Fr. United Nations Educ. Sci. Cult. Organ., 2009.

[8] S. Azisah and C. Vale, "Gender mainstreaming in Islamic primary schools in South Sulawesi, Indonesia: a textbook analysis," RIMA Rev. Indones. Malaysian Aff., vol. 42, no. 1, p. 55, 2008.

[9] S. Azisah, "Gender mainstreaming in education: case studies of Islamic primary schools in South Sulawesi, Indonesia 2000-2006." Victoria University, 2012. 